\title{
Simulating the effects of mid- to upper-tropospheric clouds on microwave emissions in EC-Earth using COSP
}

\section{S. Johnston ${ }^{1}$, G. Holl ${ }^{2}$, J. Hocking ${ }^{3}$, S. J. Cooper ${ }^{4}$, and D. Chen ${ }^{1}$}

${ }^{1}$ Department of Earth Sciences, University of Gothenburg, Gothenburg, Sweden

${ }^{2}$ Department of Meteorology, University of Reading, Reading, UK

${ }^{3}$ Satellite Applications, Met Office, Fitzroy Road, Exeter, UK

${ }^{4}$ Department Atmospheric Sciences, University of Utah, Salt Lake City, Utah, USA

Received: 29 September 2015 - Accepted: 29 October 2015 - Published: 12 November 2015 Correspondence to: M. S. Johnston (shejo284@gmail.com)

Published by Copernicus Publications on behalf of the European Geosciences Union.
Effects of mid- to upper-tropospheric water on microwave emission

M. S. Johnston et al.

\section{Title Page}

Abstract Introduction

Conclusions

References

Tables

Figures

14

4

Back

Full Screen / Esc

Printer-friendly Version

Interactive Discussion 


\section{Abstract}

In this work, the Cloud Feedback Model Intercomparison (CFMIP) Observation Simulation Package (COSP) is expanded to include scattering and emission effects of clouds and precipitation at passive microwave frequencies. This represents an advancement

over the official version of COSP (version 1.4.0) in which only clear-sky brightness temperatures are simulated. To highlight the potential utility of this new microwave simulator, COSP results generated using the climate model EC-Earth's version 3 atmosphere as input are compared with Microwave Humidity Sounder (MHS) channel $(190.311 \mathrm{GHz})$ observations. Specifically, simulated seasonal brightness temperatures $\left(T_{\mathrm{B}}\right)$ are contrasted with MHS observations for the period December 2005 to November 2006 to identify possible biases in EC-Earth's cloud and atmosphere fields.

The EC-Earth's atmosphere closely reproduces the microwave signature of many of the major large-scale and regional scale features of the atmosphere and surface. Moreover, greater than $60 \%$ of the simulated $T_{\mathrm{B}}$ are within $3 \mathrm{~K}$ of the NOAA-18 observations. However, COSP is unable to simulate sufficiently low $T_{\mathrm{B}}$ in areas of frequent deep convection. Within the Tropics, the model's atmosphere can yield an underestimation of $T_{\mathrm{B}}$ by nearly $30 \mathrm{~K}$ for cloudy areas in the ITCZ. Possible reasons for this discrepancy include both incorrect amount of cloud ice water in the model simulations and incorrect ice particle scattering assumptions used in the COSP microwave forward model. These multiple sources of error highlight the non-unique nature of the simulated satellite measurements, a problem exacerbated by the fact that EC-Earth lacks detailed micro-physical parameters necessary for accurate forward model calculations. Such issues limit the robustness of our evaluation and suggest a general note of caution when making COSP-satellite observation evaluations.
AMTD

Effects of mid- to upper-tropospheric water on microwave emission

M. S. Johnston et al.

Title Page

Abstract Introduction

Conclusions References

Tables

Figures

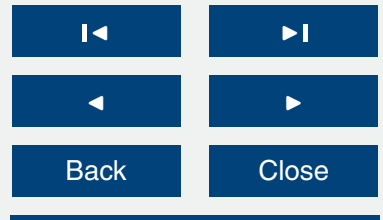

Full Screen / Esc

Printer-friendly Version

Interactive Discussion 


\section{Introduction}

Clouds are an important factor in the planet's climate system because they interact with the incoming shortwave and outgoing longwave radiation. Their precise impact on the Earth's radiative budget depends upon both their micro-physical properties (e.g. cloud 5 particle phase, size and shape) and macro-physical properties (e.g. geographical and temporal distributions). Furthermore, clouds and precipitation provide heating to the atmosphere through diabatic processes such as latent heat release. These cloud effects, in turn, interact with dynamics, convection, and water vapour in feedbacks that impact both weather and climate scale processes (see, for example Twomey, 1991; Wielicki et al., 1995; Stephens, 2005, and references therein).

Despite decades of climate modelling, simulated clouds have remained a persistent source of uncertainty in climate projections, as documented in International Panel on Climate Change (IPCC) Assessment Reports (2007 and 2013). Improved evaluation techniques for cloud representation are critical for reducing these model uncertainties

15 (Randall et al., 2007). Simulated clouds are generally a function of both the large-scale and the convection schemes of climate and Numerical Weather Prediction (NWP) models. These two schemes are often strongly interlinked, which makes it difficult to pinpoint sources of error arising from model parameterizations and assumptions. Similarly, the constraint of model cloud and precipitation fields with satellite-derived observations is problematic, due to differences in how quantities are defined and due to large uncertainties associated with operational products.

The COSP (Cloud Feedback Model Intercomparison Project (CFMIP) Observation Simulation Package) was developed to help facilitate model-to-observation comparisons. By creating a simulated cloud product that is based on a model's atmosphere but using a forward model similar to the one used to generate the observational product, COSP allows a meaningful and consistent evaluation approach. Furthermore, the COSP explicitly accounts for spatial discrepancies associated with the footprints of satellite observations and model cloud field (Bodas-Salcedo et al., 2009, 2011).
AMTD

8, 11753-11777, 2015

Effects of mid- to upper-tropospheric water on microwave emission

M. S. Johnston et al.

Title Page

Abstract Introduction

Conclusions References

Tables Figures

14

4

Back

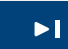

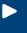

Close

Printer-friendly Version

Interactive Discussion 
The application of satellite simulators has proved useful in studies of cloud representation in models. For example, Nam and Quaas (2012) and Nam et al. (2012) used aspects of the simulator package to evaluate low and boundary layer clouds. Klein et al. (2013) examined several models for improvements in cloud representation with 5 the aid of the International Satellite Cloud Climatology Project simulator. They found improvement in some models with regards to cloud reflectivity, which they concluded lead to a reduction in compensating errors and improvement in the time-mean radiative balance, but other errors still remained. These earlier studies generally employed only 1 or 2 simulators of the 5 available in the COSP package. Given that the satellite 10 sensors considered in COSP have sensitivities to markedly different cloud and precipitation properties, it would be of great value to expand these studies and the COSP package. In fact, IPCC fifth Assessment Report (AR5) Working Group 1 (WG1) 2013, in Chapters 9-11 (http://www.climatechange2013.org), stresses the need for more tools to investigate cloud issues.

15 This study concerns the extension and improvement of COSP through inclusion of the effects of clouds and precipitation on emission and scattering in the microwave region at $190.311 \mathrm{GHz}$. Our choice of this channel is motivated by the veritable dearth of studies that examine simulated clouds and precipitation scattering at this particular frequency. This frequency is covered by one of several sounding channels close 20

to the $183 \mathrm{GHz}$ water vapour absorption line as measured by the Microwave Humidity Sounder (MHS) (Bonsignori, 2007). The smooth and linear response of MHS to clouds and precipitation makes it suitable for evaluating such aspects of the model's atmosphere (for example Geer et al., 2014; Bauer et al., 2010). However, the official version of COSP (version 1.4.0) simulates only clear-sky brightness temperatures $\left(T_{\mathrm{B}}\right)$.

Our work, therefore, involves an upgrade of COSP. Note also that this work could be extended to other microwave frequencies through selection of appropriate scattering properties in the microwave simulator forward model.

Microwave measurements of atmospheric humidity in all-sky conditions are regularly used in order to improve numerical weather prediction (for example, Geer et al., 2010).

\section{AMTD}

8, 11753-11777, 2015

\section{Effects of mid- to upper-tropospheric water on microwave emission}

M. S. Johnston et al.

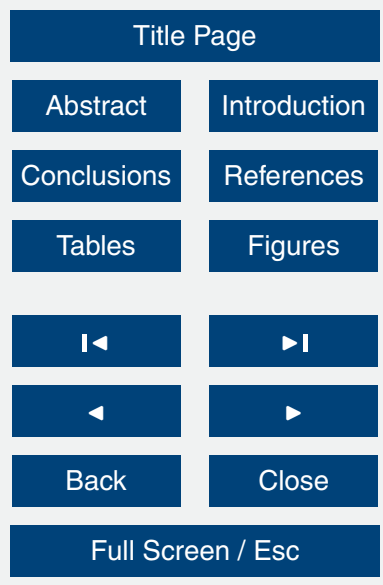

Printer-friendly Version

Interactive Discussion 
This study, however, represents the first all-sky, modelled, atmospheric microwave emission comparison with MHS $(190.311 \mathrm{GHz})$. The microwave signal is not only sensitive to mid to upper-tropospheric humidity, but also to both water and ice forms of cloud and precipitation. While ice crystals mainly scatter radiation out of the sensor's 5 line of sight (Holl et al., 2010), liquid water acts primarily as an emitter of radiation. Scattering is therefore most dominant and important in clouds with intense precipitation and/or large ice particles aloft (Geer and Baordo, 2014). The precise amount of scattering will depend not only on total ice water path but also on the ice particle shape and size distributions.

10 This study compares simulated microwave radiances generated in COSP using ECEarth cloud and precipitation profiles with MHS observations at the global scale. We explore the use of observed seasonal differences to provide insights into possible sources of bias in model profiles of cloud and precipitation properties. Section 2 briefly describes the data sources while Sect. 3 details how the data is processed in this study. 15 Results are presented in Sect. 4 and the paper concludes with a discussion and conclusion given in Sect. 5.

\section{Data}

In the following section, the data sources employed in this study are presented and briefly described.

\subsection{EC-Earth}

A general overview of the climate model EC-Earth is presented in Hazeleger et al. (2012). Only the atmospheric component is run using prescribed boundary conditions from the Era-Interim climatology (Dee et al., 2011). Version 3 of the model consists of the Cycle 36r4 of the Integrated Forecast System (IFS), which is developed and maintained at the European Centre for Medium-Range Weather Fore-

\section{AMTD}

8, 11753-11777, 2015

\section{Effects of mid- to upper-tropospheric water on microwave emission}

M. S. Johnston et al.

\section{Title Page}

Abstract Introduction

Conclusions References

Tables Figures

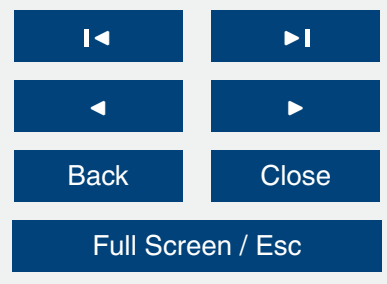

Printer-friendly Version

Interactive Discussion 
casting (ECMWF). The model resolution is set to T255 spectral resolution, or about $0.7^{\circ} \times 0.7^{\circ}$ on a reduced Gaussian grid with 91 staggered levels. The time step is $2700 \mathrm{~s}$. Aerosol information in EC-Earth is accounted for using climatologies but is not passed to COSP. Further technical details about IFS can be found at the ECWMF website 5 (https://software.ecmwf.int/wiki/display/IFS/Official+IFS+Documentation).

EC-Earth provides temperature, winds, cloud ice and water, precipitation, effective cloud fraction, surface information, for example, to COSP. The model contains four types of hydrometeors: cloud ice and cloud water and precipitating ice (snow) and rain. Cloud ice and water are treated prognostically: time derivative variables where,

10 at each time step, calculation of the new value is based on the value at the previous time step in the model. Precipitation, on the other hand, is treated diagnostically, that is, at each time step the amount is calculated from the updated prognostic variables. Cloud ice and water are expressed as mass mixing ratios $\left(\mathrm{kg} \mathrm{kg}^{-1}\right)$ and precipitation is expressed as fluxes $\left(\mathrm{kg} \mathrm{m}^{-1} \mathrm{~s}^{-1}\right)$. Before passing the hydrometeors to COSP, the 15 precipitation fluxes are first converted to mixing ratios (by dividing with the atmospheric density and assuming a constant fall speed of $1 \mathrm{~m} \mathrm{~s}^{-1}$ ) and then merged with the large scale precipitation.

\subsection{COSP-RTTOV}

COSP employs the radiative transfer model, RTTOV version 11.2 (https://nwpsaf.eu/ 20 deliverables/rtm/rtm_rttov11.html) to simulate passive microwave sensors (Saunders et al., 1999). Radiative Transfer for TOVS (RTTOV) computes the top of atmosphere radiances (brightness temperatures) for passive satellite sensors, including many microwave sensors. The RTTOV project is part of the Numerical Weather Prediction Satellite Application Facility, which is funded by the European Organisation for the Exploitation of Meteorological Satellites. RTTOV is a third party extension of COSP and extends the suite of observation simulators beyond the standard five. COSP version 1.4.0 only activates RTTOV's clear-sky simulations. However, RTTOV also contains a scattering function for passive microwave emission which uses look-up tables for 11758

\section{AMTD}

8, 11753-11777, 2015

\section{Effects of mid- to upper-tropospheric water on microwave emission}

M. S. Johnston et al.

\section{Title Page}

Abstract Introduction

Conclusions References

Tables

Figures

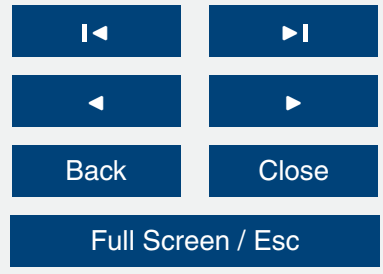

Printer-friendly Version

Interactive Discussion 
scattering information. Activating this interface requires information regarding clouds and atmospheric hydrometeors to be passed from the model, thus the COSP interface is expanded to simulate passive microwave sensors in all-sky conditions.

The information passed from EC-Earth to RTTOV includes the profiles of tempera5 ture, land-sea mask, effective cloud fraction, cloud liquid water and ice, sea ice fraction, atmospheric pressure, precipitating water and ice, and specific humidity. Surface emissivity is provided by the fast microwave emissivity model version 5 (FASTEM- 5 Bormann et al., 2012) over ocean and TELSEM (Tool to Estimate Land Surface Emissivities at Microwave frequencies) (Aires et al., 2011) over land. The land surface emissiv10 ity is derived from monthly-mean climatology of emissivities generated from microwave observations operating at frequencies below $100 \mathrm{GHz}$. These values are then interpolated for single channel emissivities at $190.311 \mathrm{GHz}$. Over water, FASTEM-5 emissivity calculations are based on surface winds, salinity, and sea surface temperature. The sea-ice parameters used with FASTEM in this study are the default set given in English 15 and Hewison (1998, Table 1).

In order to simulate the microwave scattering and absorption effects of atmospheric hydrometers, RTTOV employs the delta-Eddington approximation (Bauer et al., 2006) technique. This technique allows high speed and accurate calculations of monochromatic fluxes through the atmosphere (Joseph et al., 1976). Moreover, RTTOV uses a cloud overlap assumption, which is described in Geer et al. (2009).

All-sky brightness temperatures are calculated in two steps: first, the clear-sky $T_{\mathrm{B}}$ profiles are calculated followed by another set of calculations that include scattering effects from atmospheric constituents. The clear-sky and scattering brightness temperatures are then linearly combined using Eq. (1) to give a total brightness temperature $T_{\mathrm{B}}^{\text {Total: }}$

$T_{\mathrm{B}}^{\text {Total }}=(1-C) T_{\mathrm{B}}^{\text {Clear }}+C T_{\mathrm{B}}^{\text {Hydrometeor }}$,

\section{AMTD}

Effects of mid- to upper-tropospheric water on microwave emission

M. S. Johnston et al.

\section{Title Page}

Abstract Introduction

Conclusions References

Tables Figures

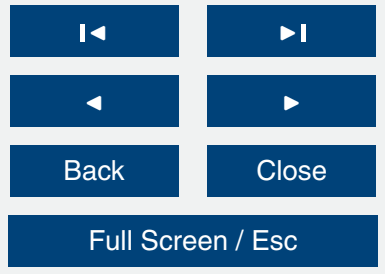

Printer-friendly Version

Interactive Discussion 
where $C$ is the effective cloud fraction profile, and $T_{\mathrm{B}}^{\text {Clear }}$ and $T_{\mathrm{B}}^{\text {Hydrometeor }}$ are brightness temperatures for clear-sky and in the presence of hydrometeor scatterers respectively. Henceforth $T_{\mathrm{B}}$ is used to mean $T_{\mathrm{B}}^{\text {Total }}$.

RTTOV uses Mie scattering tables for the bulk micro-physical properties for cloud 5 water, cloud ice, and precipitating rain. The microwave scattering routine calculates the scattering properties by integrating across a size distribution, which in this study is not provided by the model. As a result RTTOV assumes a gamma size distribution for both cloud ice and water and a Marshall and Palmer (1948) size distribution for precipitation. In both the precipitating and non-precipitating ice and water cases RTTOV also

10 assumes a constant density. The optical properties for snow particles are calculated using a discrete dipole approximation: a method used for calculating the extinction of microwave radiation by particles whose geometry and composition are non-specific (Yurkin et al., 2007). Further details and assumptions about the microwave scattering routine in RTTOV are given in Geer and Baordo (2014).

\subsection{Microwave Humidity Sounder}

This study uses data from the Microwave Humidity Sounder (MHS) on-board NOAA18, obtained from the NOAA The Comprehensive Large Array-data Stewardship System (CLASS) archive. NOAA-18 is a sun-synchronous satellite with a nominal local time ascending node of 13:30. First flown on the NOAA-18 satellite, the MHS sensor is the first instalment of its type, and succeeds the Advanced Microwave Sounding Unit B (AMSU-B) sensor (Saunders et al., 1995). MHS observes the atmosphere using 5 channels in the range $89-190 \mathrm{GHz}$ with across-track scanner consisting of 90 views in an angular range of $\pm 49.5^{\circ}$. At nadir the footprint diameter of MHS is about $17 \mathrm{~km}$. Channels 3 to 5 are centred near the strong water vapour absorption line at $183.311 \mathrm{GHz}$. Channels 3 and 4 are dual sideband channels at $183.311 \pm 1$ and $\pm 3 \mathrm{GHz}$, respectively, whereas channel 5 is located at $190.311 \mathrm{GHz}$ (http://www.ncdc.noaa.gov/oa/pod-guide/ncdc/docs/klm/html/c3/sec3-9.htm).

\section{Effects of mid- to upper-tropospheric water on microwave emission}

M. S. Johnston et al.

\section{Title Page}

Abstract Introduction

Conclusions References

Tables Figures

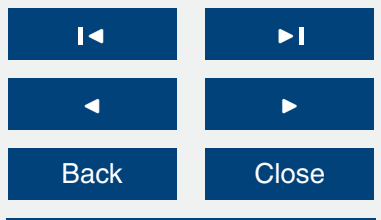

Full Screen / Esc

Printer-friendly Version

Interactive Discussion 
For a standard tropical atmosphere, the Channel 3 weighting function normally peaks in the upper troposphere, as it is closest to the centre of the water vapour absorption line. Channel 5 , being furthest from the absorption line, has a weighting function peaking in the mid-troposphere. In drier atmospheres, such as are common in cold climates 5 or at high elevations, the weighting functions for both channels move down, and Channel 5 is likely to receive surface contamination. The combination of channels $3-5$ has been used to retrieve quantitative information about atmospheric water vapour (see, for example, John et al., 2012; Buehler et al., 2005) or ice cloud and precipitation properties (Holl et al., 2014).

\section{Method}

All data used in this study are post-processed to a $1^{\circ}$ rectilinear grid. Satellite derived data are provided by the National Oceanic and Atmospheric Administration (NOAA) MHS sensor on-board the NOAA 18 satellite (NOAA-18). Only the atmospheric component of the climate model EC-Earth is used in this study. We examine the mean brightness temperature, $T_{\mathrm{B}}$, for the year December 2005 to November 2006 divided into the four seasons defined by 3 month averages: DJF, MAM, JJA, SON.

\subsection{Observation processing}

To calibrate and read MHS measurements from the NOAA CLASS archive, we used the ATOVS and AVHRR Pre-processing Package (AAPP), version 7. AAPP reads level 1-b data files and applies calibration and geolocation information, after which the calibrated $T_{\mathrm{B}}$ are generated.

We calculated the arithmetic mean for NOAA-18 MHS $T_{B}$ for each $1^{\circ} \times 1^{\circ}$ equirectangular grid cell and month (i.e. similar to a level-3 product, but generated directly from level-1 calibrated radiances). Since MHS is a cross-track scanner, the weighting function rises and radiances become colder as the satellite scan angle increases. Merging
AMTD

8, 11753-11777, 2015

Effects of mid- to upper-tropospheric water on microwave emission

M. S. Johnston et al.

\section{Title Page}

Abstract Introduction

Conclusions References

Tables Figures

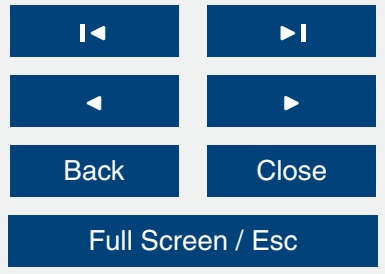

Printer-friendly Version

Interactive Discussion 
together nadir and off-nadir measurements therefore results in average radiances that are difficult to interpret. To prevent this, but still get sufficient measurements per grid cell and month, we consider MHS radiances at scan angles of at most $\pm 5^{\circ}$ off-nadir. Secondly, we collected all incidents where the criterion in Eq. (2) is fulfilled. Here, we 5 applied the same nadir angle criterion as when calculating the gridded mean $T_{\mathrm{B}}$.

In the Tropics large areas of clouds and intense precipitation are often associated with deep convective activity. To establish this fact, we identify areas of deep convection using a method developed by Hong et al. (2005). This method employs a combination of the differences between channels 3,4 and 5 to create an inequality test given in 10 Eq. (2). The inequality is satisfied only in areas of deep convection where the cloud top $T_{\mathrm{B}}$ represents a local minimum,

$\Delta T_{35} \geq \Delta T_{34} \geq \Delta T_{45}>0$,

where $\Delta T_{x y}$ is difference in $T_{\mathrm{B}}$ between channels $x$ and $y$.

\subsection{COSP-RTTOV data quality filtering}

15 Microwave radiative transfer calculations may be complicated by surface emissivity issues associated with certain surface types. For example, sea ice and snow covered surfaces may have great variability in surface emission under different conditions which in turn may translate to large uncertainties in the simulated $T_{\mathrm{B}}$. These uncertainties can be reduced using seasonal averages, although substantial biases may still remain. Well-known problem areas are filtered out from the simulation according to Geer et al. (2014, Table 3), thus enabling a fairer comparison with the NOAA-18 observations. The filtering criteria that have been adapted for this study are listed in Table 1. The simulated data were filtered at each time step before being compiled into monthly averages.

\section{AMTD}

8, 11753-11777, 2015

\section{Effects of mid- to upper-tropospheric water on microwave emission}

M. S. Johnston et al.

\section{Title Page}

Abstract Introduction

Conclusions References

Tables Figures

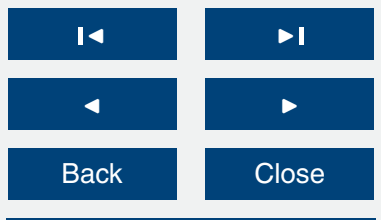

Full Screen / Esc

Printer-friendly Version

Interactive Discussion 


\section{Results}

This work primarily focuses on the effects of cloud and precipitation condensates in the Tropics on passive microwave emission at $190.311 \mathrm{GHz}$. However, we also briefly present the results poleward of $\pm 30^{\circ}$ where the effects of atmospheric water becomes 5 harder to disentangle from surface contamination. Figure 1 depicts the seasonal mean $T_{\mathrm{B}}$ calculated from RTTOV using the EC-Earth atmosphere (left column) and observed by NOAA-18 (right column) for December 2005 to November 2006. The time period is divided into four seasons: DJF (a, b), MAM (c, d), JJA (e, f), and SON (g, h).

The NOAA-18 observations show top of the atmosphere $190.311 \mathrm{GHz}$ microwave $T_{\mathrm{B}}$ 10 associated with the Earth's large scale general circulation features. The values range from near $280 \mathrm{~K}$ in the Tropics to $250 \mathrm{~K}$ over the poles. The ITCZ is clearly seen inside the Tropics as characterised by a band of reduced $T_{\mathrm{B}}$ with values typically near 260 to $270 \mathrm{~K}$. Finer scale features such as snow-covered Greenland and Antarctica and the Arctic, with its transition from ice to open water, are easily discerned in NOAA-18 5 seasonal data.

RTTOV generated $T_{\mathrm{B}}$ using EC-Earth atmosphere as input agree well to the first order with NOAA-18 observations. The overall range of $T_{\mathrm{B}}$ are similar, however, the model tends to be a bit warmer than NOAA-18 as evidenced by the broad areas with $T_{\mathrm{B}}$ around unit $280 \mathrm{~K}$ in the Tropics. The model develops a well-defined ITCZ, although it tends to be narrower in area and warmer than the NOAA-18 observations. Features poleward of $\pm 30^{\circ}$ are also captured by the model to the first order. For example, the Arctic shows significant warming in the JJA season, which is consistent with melting of the sea ice during the Boreal summer months. Finally, areas of high elevation such as the Andes, northern Rockies, Tibetan Plateau, and Himalayas tend to show similar results for both EC-Earth and NOAA-18. However, perfect agreement is not expected. Large uncertainties in assumed surface emissivity for these high-latitude and highelevation areas will result in correspondingly large uncertainties in the simulated $T_{\mathrm{B}}$.

\section{AMTD}

8, 11753-11777, 2015

Effects of mid- to upper-tropospheric water on microwave emission

M. S. Johnston et al.

Title Page

Abstract

Conclusions

Tables

Figures

14

4

Back

Printer-friendly Version

Interactive Discussion 
The NOAA-18 results suggest the presence of broad areas of lower $T_{\mathrm{B}}(\lesssim 268 \mathrm{~K})$ for all seasons within the ITCZ. These areas of low $T_{B}$ are non-contiguous, patchy and occur over both land and ocean. Such disparities are not seen over regions of subsidence, i.e. generally cloud-free areas.

5 In order to investigate the aforementioned patches of lower $T_{\mathrm{B}}$ within the ITCZ in an objective manner, we applied Eq. (2) to the NOAA-18 radiances prior to building the seasonal means. In order to match the instantaneous results from the inequality to statistical means, we assume no deep convection occurs poleward of $60^{\circ}$, which left 3080 possible cases of deep convection for the month of July 2005 . We later choose 10 a region ( -20 to $30^{\circ}$ latitude and 60 to $180^{\circ} \mathrm{E}$ longitude) and a $T_{\mathrm{B}}$ of $268 \mathrm{~K}$, which closely matches the edge of the ITCZ. Of the possible 1001 cases of deep convective events, 747 or $(\approx 75 \%)$ fall within region selected (not shown). The results strongly suggests that the patchy areas of lower $T_{\mathrm{B}}$ are largely collocated with the areas of deep convection.

15 Figure 2 quantifies $T_{\mathrm{B}}^{\mathrm{EC}-\mathrm{EARTH}}-T_{\mathrm{B}}^{\mathrm{NOAA}-18}=\Delta T_{\mathrm{B}}$. We limit the colour range of the figure to about twice the standard deviation $(\sim 5 \mathrm{~K})$ of $\Delta T_{\mathrm{B}}$ within the Tropics for better resolution at small values. Unfiltered and filtered model data are presented in the left and right panels, respectively. As above, unfiltered $\Delta T_{\mathrm{B}}\left(\Delta T_{\mathrm{B}}^{\mathrm{UF}}\right)$ includes areas where there are large uncertainties in the simulated results due to assumed surface emis20 sivity, e.g. snow or sea ice conditions. The filtered $\Delta T_{\mathrm{B}}\left(\Delta T_{\mathrm{B}}^{F}\right)$ data, by removing low confidence values according to Table 1 , allows us to better focus on the impact of clouds and precipitation.

The results show that the spread in $\Delta T_{\mathrm{B}}^{\mathrm{UF}}$ can reach $\sim \pm 10 \mathrm{~K}$, and locally up to $\sim$ $\pm 40 \mathrm{~K}$ (not shown) for all seasons. The ITCZ consistently contains regions of positive ${ }_{25} \Delta T_{\mathrm{B}}$, suggesting a systematic bias in the model's atmosphere when calculating $T_{\mathrm{B}}$ in areas of convective clouds. Despite the clear bias in the ITCZ, the figures show many regions with a $\Delta T_{\mathrm{B}}$ within $\approx \pm 3 \mathrm{~K}$.

Table 2 provides a statistical description of Fig. 2. The table presents the mean and standard deviation of $\Delta T_{\mathrm{B}}$ as well as the percentage of grid boxes where $\left|\Delta T_{\mathrm{B}}\right| \leq 3 \mathrm{~K}$.
AMTD

8, 11753-11777, 2015

Effects of mid- to upper-tropospheric water on microwave emission

M. S. Johnston et al.

\section{Title Page}

Abstract Introduction

Conclusions References

Tables Figures

14

4

Back

Full Screen / Esc

Printer-friendly Version

Interactive Discussion 
Filtering has a greater effect for places where $\Delta T_{\mathrm{B}}<0$. This can be seen in the global standard deviation, which is reduced by half. However, over Europe during the DJF season the filtering seems to reverse the bias, which is likely a function of snow-covered surfaces occurring sometime during the DJF season. In cloudy regions, the differences 5 for both $\Delta \mathrm{T}_{\mathrm{B}}^{\mathrm{UF}}$ and $\Delta \mathrm{T}_{\mathrm{B}}^{\mathrm{F}}$ are consistently positive with a mean on the order of $\sim 2 \mathrm{~K}$, which locally can be as large as $\sim 30 \mathrm{~K}$. This bias is consistently observed in the ITCZ. This could result from too little IWC in EC-Earth in these areas of deep convection or from the scattering assumptions made about the cloud and hydrometeor micro-physical properties used in the COSP simulation. This is supported by Geer et al. (2014) who 10 stated that in RTTOV, scattering is reduced (thereby increasing $T_{\mathrm{B}}$ ) in the Tropics in order to compensate for an over-estimation at higher latitudes. In summary, it seems that the model's atmosphere produces lower $T_{\mathrm{B}}$ when there are few or no clouds and too high $T_{\mathrm{B}}$ when there are clouds. Despite this fact, the percentage of grid boxes where $\Delta \mathrm{T}_{\mathrm{B}}$ is within $3 \mathrm{~K}$ is $\sim 59$ to $73 \%$ throughout the period.

15 Figure 3 is a plot of the zonally averaged mean brightness temperature for both NOAA-18 and model simulated observations along with the resulting $\Delta T_{B}$. Figure 4 quantifies the probability density function (PDF) of $\Delta T_{B}$ both within and outside the Tropics. Both figures show a consistently positive zonal bias within the Tropics of $\approx 3-$ $5 \mathrm{~K}$ for the simulated model observations, with the largest biases occurring in the cloudy areas of the ITCZ. Polewards of $\pm 60^{\circ}$ the zonal mean of $\Delta \mathrm{T}_{\mathrm{B}}^{\mathrm{UF}}$ can become quite large both positively and negatively. However, for the $\Delta T_{B}^{F}$, the zonal mean (solid black) tends to remain positive and seems to result in a poorer agreement with NOAA-18 for all but the SON season. Furthermore, the modelled atmosphere mostly displays a positive bias in the zonal $T_{\mathrm{B}}^{\mathrm{UF}}$ and $\Delta T_{\mathrm{B}}^{\mathrm{F}}$. Further quantification of $\Delta T_{\mathrm{B}}^{\mathrm{UF}}$ is given in Fig. 4, which shows, for all seasons, there is a bias of $\approx 3 \mathrm{~K}$ for a majority of the data.
AMTD

8, 11753-11777, 2015

Effects of mid- to upper-tropospheric water on microwave emission

M. S. Johnston et al.

Title Page

Abstract Introduction

Conclusions References

Tables Figures

14

$>$ I

4

Back

Full Screen / Esc

Printer-friendly Version

Interactive Discussion 


\section{Discussion and conclusions}

In this study, the satellite simulator COSP is upgraded to include clouds and precipitation in its calculations of microwave radiances. This represents an advancement over the official version of COSP (version 1.4.0) in which only clear-sky brightness tem5 peratures are simulated. The calculations associated with hydrometeor scattering and emission are accomplished modifying of the RTTOV forward model interface used for the clear-sky conditions in the COSP simulator.

Microwave radiances generated from COSP, assuming an EC-Earth atmosphere, were compared with MHS $(190.311 \mathrm{GHz})$ observations for the year 2006 at the global 10 scale. By focusing on seasonal time scales, we minimise any bias in our analyses caused by spatio-temporal errors in the modelled clouds and precipitation fields. Clearsky calculations are omitted from the study.

The results (Figs. 1-4) show good agreement between microwave brightness temperatures as simulated using the EC-Earth atmosphere and those observed from 15 NOAA-18 for some key atmospheric features, e.g. ITCZ and areas of large-scale subsidence. However, there are regions with clear large biases whose signs (positive/negative) are seasonally dependent (for example western North America). These regions of large biases are known problematic issues when conducting $T_{\mathrm{B}}$ calculations above certain surface types. These regions of the simulated $T_{\mathrm{B}}$ were filtered according to Table 1, and affected mostly the high latitudes of the Northern Hemisphere. For subsidence areas with generally low cloud frequency, the model atmosphere shows a lower $T_{\mathrm{B}}$ than NOAA-18, possibly indicating too little surface or water vapour emission in the simulated radiances.

In most cases where clouds are present, the model tends to overestimate the $T_{\mathrm{B}}$. 25 For deep convective regions within the ITCZ with significant ice cloud and precipitation aloft, observed zonal MHS $T_{\mathrm{B}}$ are $3 \mathrm{~K}$ greater than corresponding COSP simulated values. Locally, this difference can be much higher $(\sim 30 \mathrm{~K})$. This discrepancy could occur if EC-Earth has either too little ice aloft or if the assumed cloud and hydrometeor
AMTD

8, 11753-11777, 2015

Effects of mid- to upper-tropospheric water on microwave emission

M. S. Johnston et al.

\section{Title Page}

Abstract Introduction

Conclusions References

Tables Figures

14 4 Back
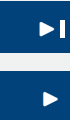

Close

Full Screen / Esc

Printer-friendly Version

Interactive Discussion 
properties in the radiative transfer simulations resulting in too little scattering per given ice water path. Nevertheless, over $60 \%$ of the simulated $T_{\mathrm{B}}$ fall within $3 \mathrm{~K}$ of NOAA-18.

Although the analyses in this work demonstrate seasonal biases between model and observations, it is difficult to confidently identify the source(s). The models may produce 5 the incorrect amount of cloud (ice or water) or distribute it poorly in the vertical (Eliasson et al., 2011). Likewise, the distribution of water vapour may not well represent real world conditions. Of course, errors in all these model fields, among others, could conspire to produce a microwave signature close to MHS observations. It is possible that the use of other sensors available in COSP, or other microwave frequencies, may provide insight 10 into these biases, as each of these measurements have different sensitivities to the vertical profile of cloud and precipitation properties.

Another possible source of bias in this study involves the forward model assumptions used to translate between model physical fields and microwave $T_{\mathrm{B}}$. For example, as noted above, the RTTOV forward model calculates the snow micro-physical proper15 ties using the discrete dipole approximation, while for other particle types it assumes particles are spherical and uses Mie theory to calculate particle scattering properties. As described in Geer and Baordo (2014) determining realistic assumptions for scattering particle properties is extremely challenging. This is expected therefore to contribute to the warm biases seen in the simulations of the convective ice profiles.

Our results are largely consistent with those of Geer and Baordo (2014) whose work involved the assimilation of microwave frequencies into the IFS numerical weather prediction model that makes up the atmospheric core of EC-Earth. This work also noted the possible under-representation of scattering in deep convective areas at high microwave frequencies. The use of scattering properties based upon the Discrete Dipole

25 Approximation (DDA) for non-spherical ice particles leads to a reduction in observed errors relative to the assumption of Mie theory and ice spheres. The use of a "one size fits all" cloud micro-physics resulted in a compromise where RTTOV's choice of DDA snow habit underestimates scattering in the Tropics in order to reduce an overestimation elsewhere (Geer and Baordo, 2014). Given that our study found that $>60 \%$ of

\section{AMTD}

8, 11753-11777, 2015

Effects of mid- to upper-tropospheric water on microwave emission

M. S. Johnston et al.

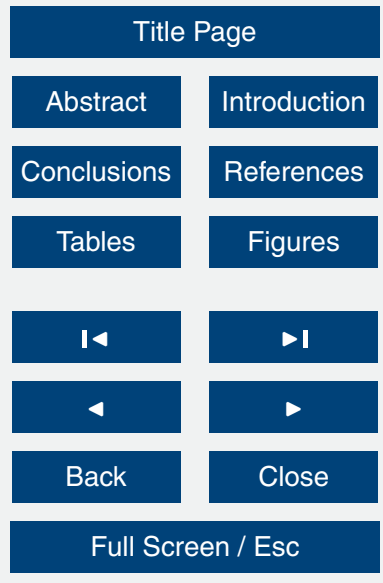

Printer-friendly Version

Interactive Discussion 
the time the simulated $T_{\mathrm{B}}$ is within $3 \mathrm{~K}$ of NOAA-18, perhaps this is currently the best that can be provided. This margin of agreement is similar to Geer and Baordo (2014, Fig. $8 \mathrm{~b}) \pm 4 \mathrm{~K}$ for first guess departures for DDA for snow at $52.8 \mathrm{GHz}$. A possible improvement for future studies could involve a departure from a global micro-physics to 5 one that is more regional.

Our results highlight the inherent non-uniqueness of the COSP simulated microwave observation, meaning that multiple different combinations of cloud and precipitation properties can yield the same $T_{\mathrm{B}}$. This issue is further complicated by the fact that ECEarth does not provide detailed micro-physical information (few, if any, models do) on critical properties such as ice particle habit or size distribution needed in the radiative transfer calculations. Such limitations suggest caution when comparing COSP simulator results with real-world observations in attempt to evaluate model physical fields, e.g. vertical profiles of cloud, precipitation, and water vapour.

Acknowledgements. The research presented in this paper is a contribution to the strategic 15 research area Modelling the Regional and Global Earth System, MERGE. The RTTOV software is developed with funding from EUMETSAT via the Satellite Applications Facility for Numerical Weather Prediction (NWP SAF). Our work have achieved its high level of quality thanks in large part to the help provided by Alan Geer from the European Centre for Medium-Range Weather Forecasts, Reading, England; Mathias Milz at Luleå University of Technology; Klaus Wyser and Martin Evaldsson from the Swedish Meteorological and Hydrological Institute in Norrköping, Sweden; and Hamish Struthers from the National Supercomputer Centre in Linköping, Sweden.

\section{References}

Aires, F., Prigent, C., Bernardo, F., Jiménez, C., Saunders, R., and Brunel, P.: A Tool to Estimate Land-Surface Emissivities at Microwave frequencies (TELSEM) for use in numerical weather prediction, Q. J. R. Meteorol. Soc., 137, 690-699, doi:10.1002/qj.803, 2011. 11759

Bauer, P., Moreau, E., Chevallier, F., and O'Keeffe, U.: Multiple-scattering microwave radiative transfer for data assimilation applications, Q. J. R. Meteorol. Soc., 132, 1259-1281, doi:10.1256/qj.05.153, 2006. 11759

\section{AMTD}

\section{Effects of mid- to upper-tropospheric water on microwave emission}

M. S. Johnston et al.

\section{Title Page}

Abstract Introduction

Conclusions References

Tables Figures

14

4

Back

Full Screen / Esc

Printer-friendly Version

Interactive Discussion 
Bauer, P., Geer, A. J., Lopez, P., and Salmond, D.: Direct 4D-Var assimilation of all-sky radiances. Part I: Implementation, Q. J. R. Meteorol. Soc., 136, 1868-1885, 2010. 11756

Bodas-Salcedo, A., Webb, M. J., Brooks, M. E., Ringer, M. A., Williams, K. D., Milton, S. F., and Wilson, D. R.: Evaluating cloud systems in the met office global forecast model using simulated CloudSat radar reflectivities, J. Geophys. Res.: Atmos., 114, 1-18, doi:10.1029/2007JD009620, 2009. 11755

Bodas-Salcedo, A., Webb, M. J., Bony, S., Chepfer, H., Dufresne, J. L., Klein, S. A., Zhang, Y., Marchand, R., Haynes, J. M., Pincus, R., and John, V. O.: COSP: Satellite simulation software for model assessment, B. Am. Meteorol. Soc., 92, 1023-1043, doi:10.1175/2011BAMS2856.1, 2011. 11755

Bonsignori, R.: The microwave humidity sounder MHS in-orbit performance assessment - art. no. 67440A, in: Sensors, Systems, and Next-Generation Satellites XI, edited by: Meynart, R., Neeck, S. P., Shimoda, H., and Habib, S., vol. 6744 of Proceedings of the Society of PhotoOptical Instrumentation Engineers (SPIE), p. A7440, SPIE-INT SOC OPTICAL ENGINEERING, 1000 20TH ST, PO BOX 10, BELLINGHAM, WA 98227-0010 USA, Conference on Sensors, Systems, and Next-Generation Satellites XI, Florence, Italy, 17-20 September 2007. 11756

Bormann, N., Geer, A., and English, S.: Evaluation of the Microwave Ocean Surface Emmisivity Model FASTEM-5 in the IFS, Technical Memorandum 667, European Centre for MediumRange Weather Forecasts, Reading, England, 2012. 11759

Buehler, S., Eriksson, P., Kuhn, T., von Engeln, A., and Verdes, C.: ARTS, the atmospheric radiative transfer simulator, J. Quant. Spectrosc. Ra., 91, 65-93, doi:10.1016/j.jqsrt.2004.05.051, 2005. 11761

Dee, D. P., Uppala, S. M., Simmons, A. J., Berrisford, P., Poli, P., Kobayashi, S., Andrae, U., Balmaseda, M. A., Balsamo, G., Bauer, P., Bechtold, P., Beljaars, A. C. M., van de Berg, L., Bidlot, J., Bormann, N., Delsol, C., Dragani, R., Fuentes, M., Geer, A. J., Haimberger, L., Healy, S. B., Hersbach, H., Hólm, E. V., Isaksen, L., Kållberg, P., Köhler, M., Matricardi, M., Mcnally, A. P., Monge-Sanz, B. M., Morcrette, J. J., Park, B. K., Peubey, C., de Rosnay, P., Tavolato, C., Thépaut, J. N., and Vitart, F.: The ERA-Interim reanalysis: configuration and performance of the data assimilation system, Q. J. R. Meteorol. Soc., 137, 553-597, doi:10.1002/qj.828, 2011. 11757

\section{AMTD}

$8,11753-11777,2015$

\section{Effects of mid- to upper-tropospheric water on microwave emission}

M. S. Johnston et al.

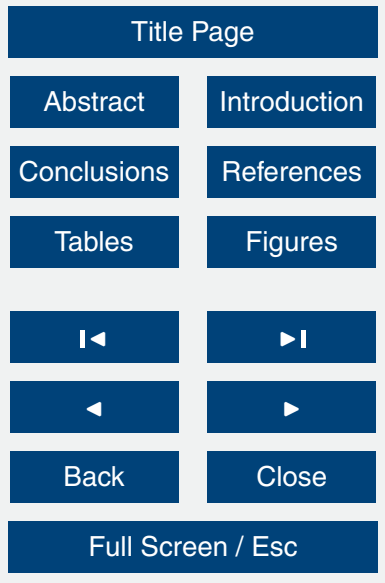

Printer-friendly Version

Interactive Discussion 
Eliasson, S., Buehler, S. A., Milz, M., Eriksson, P., and John, V. O.: Assessing observed and modelled spatial distributions of ice water path using satellite data, Atmos. Chem. Phys., 11, 375-391, doi:10.5194/acp-11-375-2011, 2011. 11767

English, S. J. and Hewison, T. J.: Fast generic millimeter-wave emissivity model, Proc. SPIE, 3503, 288-300, doi:10.1117/12.319490, 1998. 11759

Geer, A., Baordo, F., Bormann, N., and English, S.: All-sky assimilation of microwave humidity sounders, Technical Technical Memorandum 741, European Centre for MediumRange Weather Forecasts (ECMWF), Reading, England, http://www.ecmwf.int/en/research/ publications (last access: 8 November 2015), 2014. 11756, 11762, 11765, 11772

10 Geer, A. J. and Baordo, F.: Improved scattering radiative transfer for frozen hydrometeors at microwave frequencies, Atmos. Meas. Tech., 7, 1839-1860, doi:10.5194/amt-7-1839-2014, 2014. 11757, 11760, 11767, 11768

Geer, A. J., Bauer, P., and O'Dell, C. W.: A revised cloud overlap scheme for fast microwave radiative transfer in rain and cloud, J. Appl. Meteor. Climatol., 48, 2257-2270, 2009. 11759

Geer, A. J., Bauer, P., and Lopez, P.: Direct 4D-Var assimilation of all-sky radiances. Part II: Assessment, Q. J. R. Meteorol. Soc., 136, 1886-1905, 2010. 11756

Hazeleger, W., Wang, X., Severijns, C., Ştefănescu, S., Bintanja, R., Sterl, A., Wyser, K., Semmler, T., Yang, S., and den Hurk, B.: EC-Earth V2.2: description and validation of a new seamless earth system prediction model, Clim. Dynam., 39, 2611-2629, 2012. 11757

20

Holl, G., Buehler, S. A., Rydberg, B., and Jiménez, C.: Collocating satellite-based radar and radiometer measurements - methodology and usage examples, Atmos. Meas. Tech., 3, 693708, doi:10.5194/amt-3-693-2010, 2010. 11757

Holl, G., Eliasson, S., Mendrok, J., and Buehler, S.: SPARE-ICE: synergistic ice water path from passive operational sensors, J. Geophys. Res.: Atmos., 119, 1504-1523, 2014. 11761

Hong, G., Heygster, G., Miao, J., and Kunzi, K.: Detection of tropical deep convective clouds from AMSU-B water vapor channels measurements, J. Geophys. Res. D: Atmos., 110, 1-15, doi:10.1029/2004JD004949, 2005. 11762

John, V. O., Holl, G., Buehler, S. A., Candy, B., Saunders, R. W., and Parker, D. E.: Understanding intersatellite biases of microwave humidity sounders using global simultane2012. 11761

AMTD

8, 11753-11777, 2015

\section{Effects of mid- to upper-tropospheric water on microwave emission}

M. S. Johnston et al.

\section{Title Page}

Abstract Introduction

Conclusions References

Tables Figures

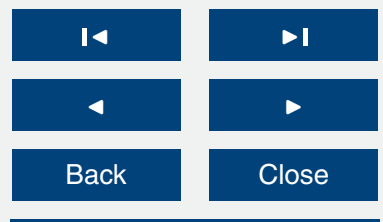

Full Screen / Esc

Printer-friendly Version

Interactive Discussion 
Joseph, J. H., Wiscombe, W. J., and Weinman, J. A.: The Delta-Eddington Approximation for Radiative Flux Transfer, J. Atmos. Sci., 33, 2452-2459, doi:10.1175/15200469(1976)033<2452:TDEAFR>2.0.CO;2, 1976. 11759

Klein, S. A., Zhang, Y., Zelinka, M. D., Pincus, R., Boyle, J., and Gleckler, P. J.: Are climate 5 model simulations of clouds improving? An evaluation using the ISCCP simulator, J. Geophys. Res.: Atmos., 118, 1329-1342, doi:10.1002/jgrd.50141, 2013. 11756

Marshall, J. S. and Palmer, W. M. K.: The distribution of raindrops with size, J. Meteor., 5, 165-166, 1948. 11760

Nam, C., Bony, S., Dufresne, J. L., and Chepfer, H.: The too few, too bright tropical low-cloud problem in CMIP5 models, Geophys. Res. Lett., 39, 1-7, doi:10.1029/2012GL053421, 2012. 11756

Nam, C. C. W. and Quaas, J.: Evaluation of clouds and precipitation in the ECHAM5 general circulation model using CALIPSO and cloudsat satellite data, J. Clim., 25, 4975-4992, doi:10.1175/JCLI-D-11-00347.1, 2012. 11756

Randall, D. A., Wood, R. A., Bony, S., Colman, R., Fichefet, T., Fyfe, J., Kattsov, V., Pitman, A., Shukla, J., Srinivasan, J., Stouffer, R. J., Sumi, A., and Taylor, K. E.: Climate models and their evaluation, in: Climate Change 2007: The physical science basis. Contribution of Working Group I to the Fourth Assessment Report of the IPCC (FAR), University Press, Cambridge, United Kingdom and New York, NY, USA, 589-662, 2007. 11755

Saunders, R., Hewison, T., Stringer, S., and Atkinson, N.: The radiometric characterization of AMSU-B, IEEE T. Microw. Theory, 43, 760-771, 1995. 11760

Saunders, R., Matricardi, M., and Brunel, P.: An improved fast radiative transfer model for assimilation of satellite radiance observations, Q. J. R. Meteorolog. Soc., 125, 1407-1425, 1999. 11758

Stephens, G. L.: Cloud feedbacks in the climate system: a critical review, J. Clim., 18, 237-273, 2005. 11755

Twomey, S.: Aerosols, clouds and radiation, Atmos. Environ. A, 25, 2435-2442, doi:10.1016/0960-1686(91)90159-5, 1991. 11755

Wielicki, B., Cess, R., King, M., Randall, D., and Harrison, E.: Mission to planet Earth - Role of clouds and radiation in climate, B. Am. Meteorol. Soc., 76, 2125-2153, 1995. 11755

Yurkin, M. A., Maltsev, V. P., and Hoekstra, A. G.: The discrete dipole approximation for simulation of light scattering by particles much larger than the wavelength, J. Quant. Spectrosc. Radiat. Transfer, 106, 546-557, doi:10.1016/j.jqsrt.2007.01.033, 2007. 11760

\section{AMTD}

8, 11753-11777, 2015

\section{Effects of mid- to upper-tropospheric water on microwave emission}

M. S. Johnston et al.

\section{Title Page}

Abstract Introduction

Conclusions References

Tables Figures

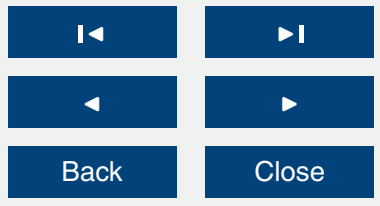

Full Screen / Esc

Printer-friendly Version

Interactive Discussion 
Table 1. List of the data quality criteria used to filter the COSP simulation. (Adapted from Geer et al., 2014, Table 3).

Latitude poleward of $\pm 60^{\circ}$

Orography greater than $800 \mathrm{~m}$

Fractional land-sea mask $(0.2-0.8)$

A sea-ice fraction greater than 0

Over ocean, surface temperatures $<274 \mathrm{~K}$

Snow-covered land areas

AMTD

8, 11753-11777, 2015

Effects of mid- to upper-tropospheric water on microwave emission

M. S. Johnston et al.

Title Page

Abstract

Introduction

Conclusions

References

Tables

Figures

14

4

Back

Close

Full Screen / Esc

Printer-friendly Version

Interactive Discussion 


\section{AMTD}

8, 11753-11777, 2015

\section{Effects of mid- to upper-tropospheric water on microwave emission}

Table 2. Table of the average, standard deviation, and the percentage of grid boxes where the difference $T_{\mathrm{B}}^{\mathrm{EC}-\mathrm{EARTH}}-T_{\mathrm{B}}^{\mathrm{NOAA}-18}$ is greater is within a reasonable uncertainty assumption of $3 \mathrm{~K}$. Statistics taken over the globally and the Tropics for the unfiltered and filtered data. The filtered data are given in parentheses.

\begin{tabular}{lllllll}
\hline & \multicolumn{2}{c}{ Mean } & \multicolumn{2}{c}{ SD } & \multicolumn{2}{c}{$\left|\Delta T_{\mathrm{B}}\right| \leq 3$} \\
\cline { 2 - 7 } Season & Global [K] & Tropics [K] & Global [K] & Tropics [K] & Global [\%] & Tropics [\%] \\
\hline DJF & $1.7(1.9)$ & $2.0(1.9)$ & $5.2(3.2)$ & $3.1(3.0)$ & $62.2(70.8)$ & $67.1(68.7)$ \\
MAM & $2.4(2.0)$ & $2.2(2.1)$ & $5.1(2.7)$ & $3.0(2.9)$ & $59.4(69.4)$ & $73.2(65.1)$ \\
JJA & $1.9(1.8)$ & $2.1(2.1)$ & $4.6(2.6)$ & $3.1(3.0)$ & $68.3(73.7)$ & $66.5(68.2)$ \\
SON & $1.5(1.9)$ & $2.4(2.3)$ & $4.3(2.7)$ & $3.0(2.9)$ & $63.6(72.3)$ & $63.6(66.0)$ \\
\hline
\end{tabular}

Title Page

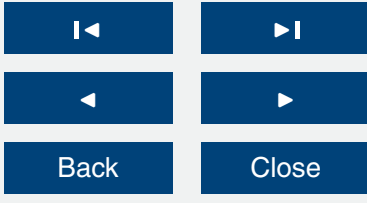

Full Screen / Esc

Printer-friendly Version

Interactive Discussion 

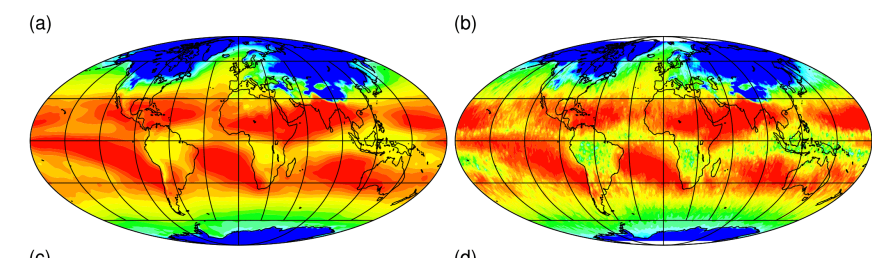

(c)

(d)
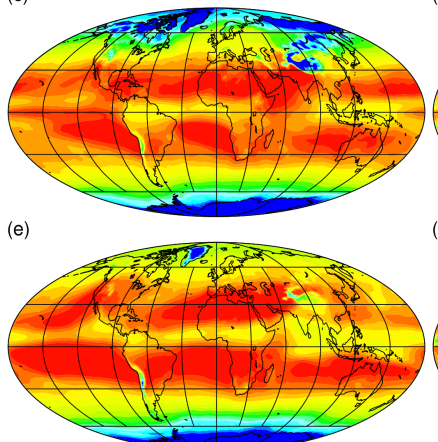

(g)

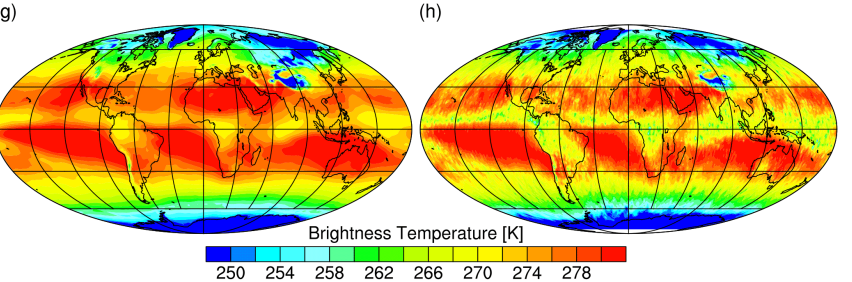

Figure 1. Seasonal (December 2005 to November 2006) satellite-derived mean $T_{\mathrm{B}}$, expressed in Kelvin, at $190.311 \mathrm{GHz}$, simulated using COSP (left column: a, c, e, and g) and NOAA18 MHS sensor (right column: $\mathbf{b}, \mathbf{d}, \mathbf{f}$, and $\mathbf{h}$ ). The seasons are displayed as follows: DJF: (a, b), MAM: (c, d), JJA: (e, f), and SON: (g, h).

\section{AMTD}

8, 11753-11777, 2015

Effects of mid- to upper-tropospheric water on microwave emission

M. S. Johnston et al.

\section{Title Page}

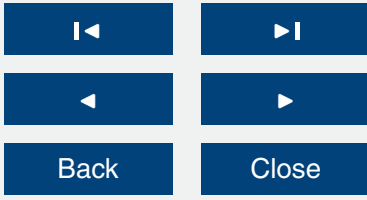

Full Screen / Esc

Printer-friendly Version

Interactive Discussion 


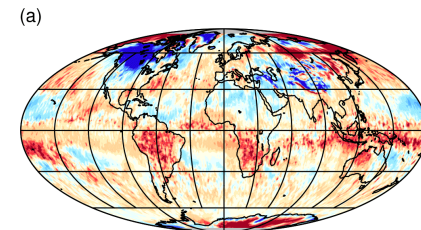

(b)

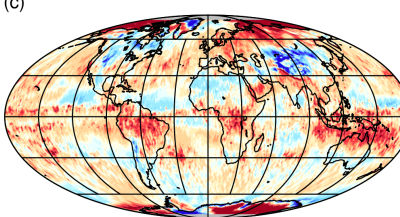

(e)
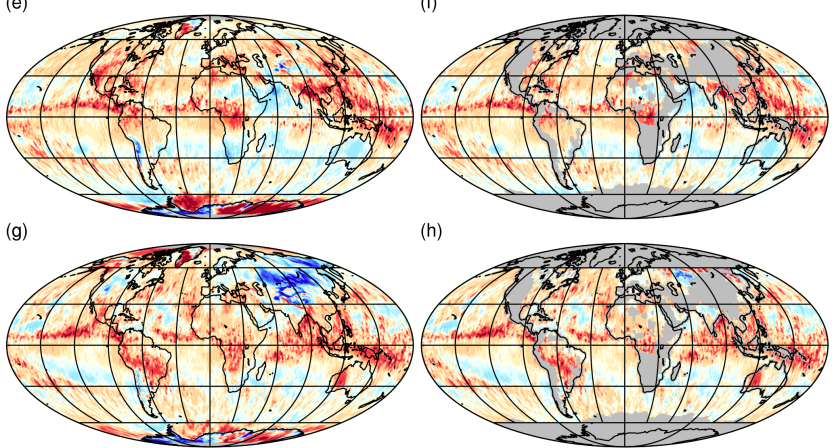

Brightness Temperature [K]

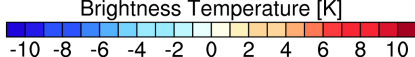

Figure 2. 2006 difference $\left(T_{\mathrm{B}}^{\mathrm{EC}-\mathrm{EARTH}}-T_{\mathrm{B}}^{\mathrm{NOAA}-18}=\Delta T_{\mathrm{B}}\right)$ in seasonal satellite-derived mean $T_{\mathrm{B}}$, expressed in Kelvin, at $190.311 \mathrm{GHz}$, simulated using COSP-RTTOV MHS simulator. The column on the left depicts the differences without filtering, while the right column shows the differences filtered according to Table 1 . The seasons are in each row as: DJF: (a, b), MAM: (c, d), JJA: $(\mathbf{e}, \mathbf{f})$, and SON: $(\mathbf{g}, \mathbf{h})$. The filtered areas are depicted as gray.
AMTD

8, 11753-11777, 2015

Effects of mid- to upper-tropospheric water on microwave emission

M. S. Johnston et al.

Title Page

Abstract

Introduction

Conclusions

References

Tables

Figures

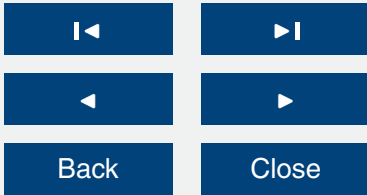

Full Screen / Esc

Printer-friendly Version

Interactive Discussion 

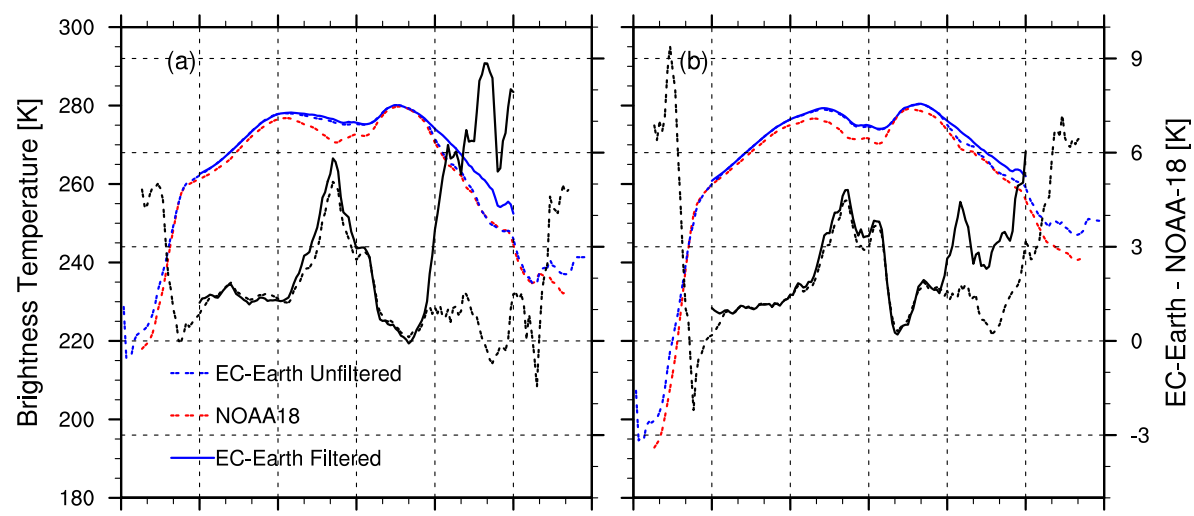

AMTD

$8,11753-11777,2015$
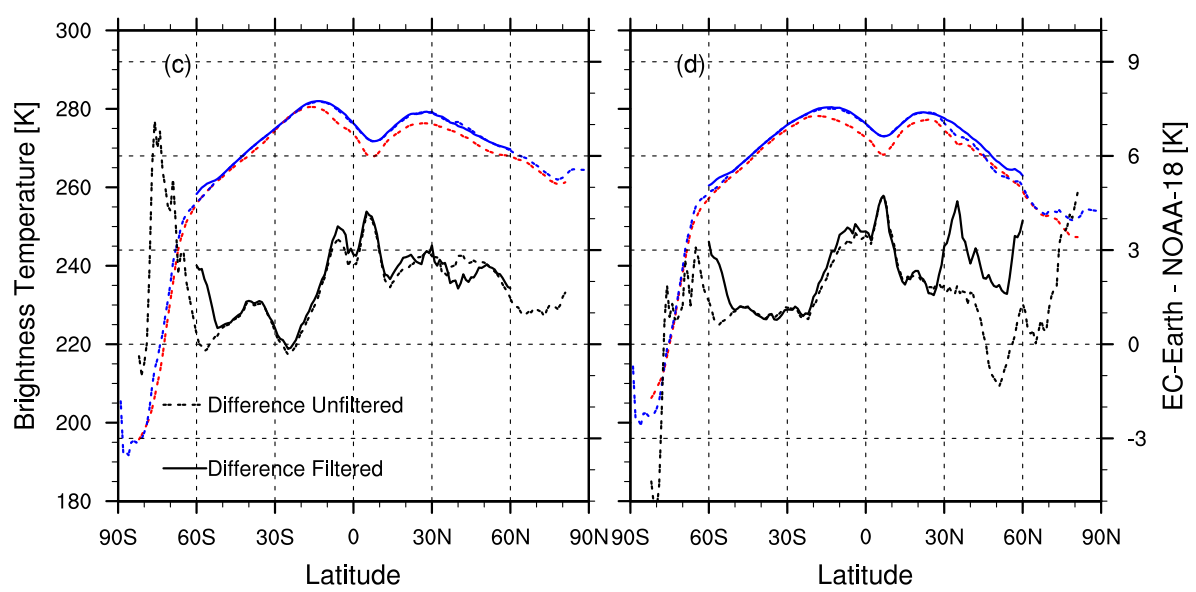

Title Page

Abstract

Introduction

Conclusions

References

Tables

Figures

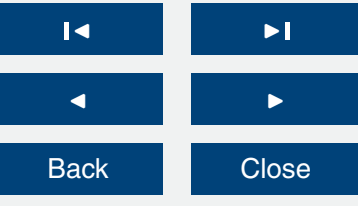

Full Screen / Esc

Figure 3. Seasonal zonal mean $T_{\mathrm{B}}$ for channel $5(190.311 \mathrm{GHz})$ of the NOAA-18 MHS sensor (red) and EC-Earth-COSP simulated (blue). The black line shows the zonal mean of $\Delta T_{B}^{U F}$. The data for the filtered case are depicted by solid lines. DJF represented by (a) MAM by (b), JJA by (c), and SON by (d).

Printer-friendly Version

Interactive Discussion

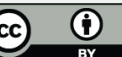




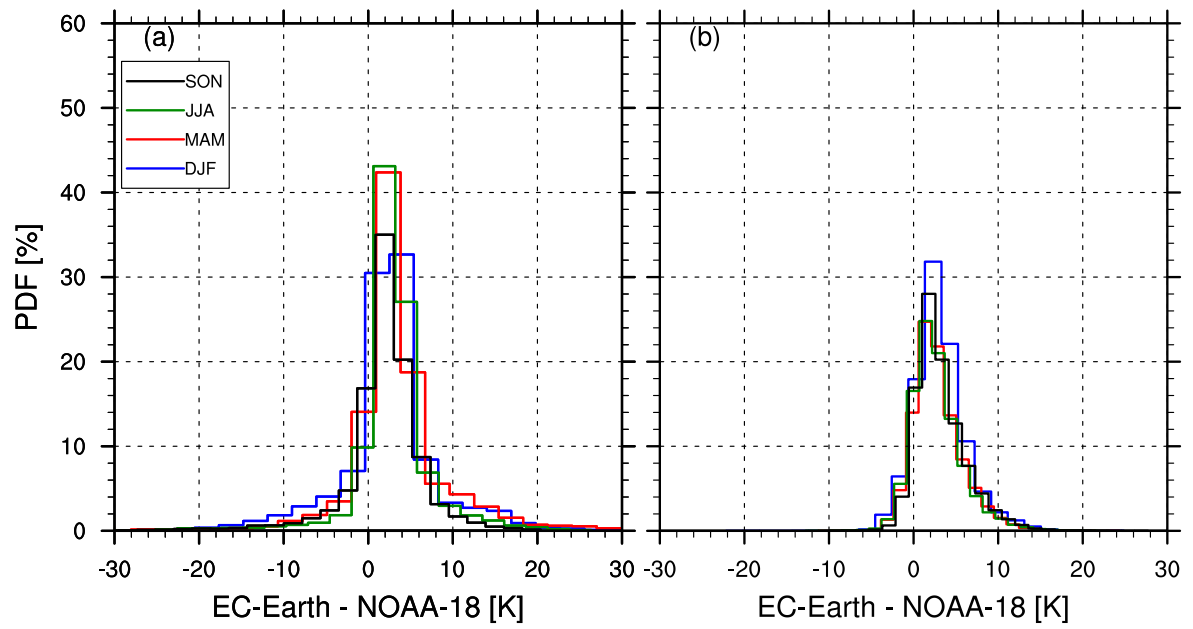

Figure 4. Probability density function of $\Delta T_{\mathrm{B}}^{\mathrm{UF}}$ for channel $5(190.311 \mathrm{GHz})$. Plot (a) depicts the differences poleward of \pm 30 latitude and plot (b) between \pm 30 latitude. Note: plots shows a shortened $\mathrm{X}$-axis in order to increase focus on the centre the plot.

\section{AMTD}

8, 11753-11777, 2015

\section{Effects of mid- to upper-tropospheric water on microwave emission}

M. S. Johnston et al.

\section{Title Page}

Full Screen / Esc

Printer-friendly Version

Interactive Discussion 